\title{
Bacterioplankton and phytoplankton production in a large patagonian reservoir (República Argentina)
}

\author{
Miguel A. Di Siervi, Aldo A. Mariazzi \& Jorge L. Donadelli \\ Instituto de Limnología. Facultad de Ciencias Naturales y Museo; Universidad Nacional de La Plata, Calle $51 n^{\circ}$ \\ 484. C C 712-1900 La Plata, República Argentina
}

Received 4 August 1993; in revised form 3 December 1993; accepted 26 January 1994

Key words: bacteria, thymidine incorporation, primary production, spatial time variations

\begin{abstract}
Relationships between the secondary production of bacterioplankton and the primary production of phytoplankton in the Ezequiel Ramos Mexia Reservoir were examined. Monthly surveys, parallel measurements on consecutive days, and measurements at different times during the same day were undertaken to determine factors that might influence the relationships between the two sets of productivity measurements.

The vertical and seasonal distribution of bacterial production appeared to be strongly related to primary production, with temperature as an important component of this trend. The bacterial production in the water column was equivalent to between 2 and $45 \%$ of the phytoplankton production over a period of one year.

In a diel study, bacterial secondary production rates fluctuated, with maximum values during the night and early morning. There was no temporal coincidence between algal primary production and bacterial secondary production in daily surveys. It was therefore concluded that isolated measurements of productivity reflect events only at the particular time at which they are obtained. The relationship between algae and bacteria is extremely complex and must be carefully evaluated. The nature of the relationship could be underevaluated if the only measurements taken into consideration were made during the daylight period.
\end{abstract}

\section{Introduction}

Phytoplankton can provide organic carbon to bacteria directly, either through excretion (Sharp, 1977; Larsson \& Hagström, 1982), or through the lysis of dead cells. On the other hand, bacteria, in their role as mineralizers, may provide the phytoplankton with nutrients. Under such circumstances growth of the phytoplanktonic will be directly dependent on bacterial activity. But an important factor is the time scale of the coupling between phytoplankton and bacteria (Fuhrman et al., 1985).

Generally, the correlation between bacterial and phytoplankton production is based on overlaps over large scales or over seasons (Cole et al., 1988), but the relationships between phytoplankton and bacterial production can vary greatly, particularly over short- er temporal and spatial scales (McManus \& Peterson, 1988).

The aim of this study was to estimate bacterial secondary production and algal primary production over varying spatial and temporal (up to annual) scales, in and attempt to throw more light onto the complex relationships between bacteria and algae. Daily and diel variations were also included to emphasize the possibility of incorrect interpretation of the interdependence of key variables.

\section{Study site}

The Ezequiel Ramos Mexỉa Reservoir was formed by damming the Limay River during 1972. It is located at $39^{\circ} 20^{\prime} \mathrm{S}$ and $68^{\circ} 20^{\prime} \mathrm{W}$ (República Argentina). The 


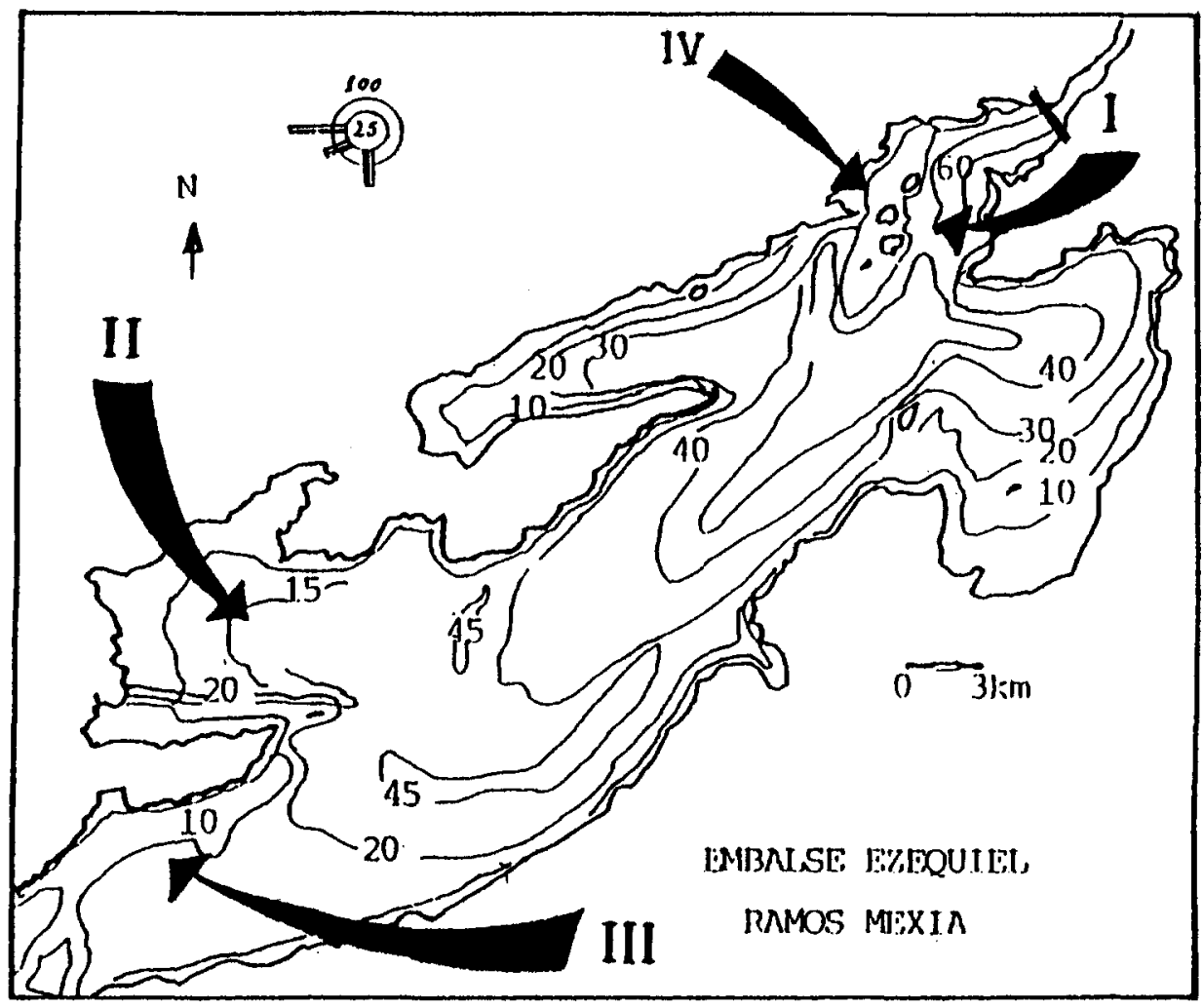

Fig. 1. Ezequiel Ramos Mexia Reservoir with sampling stations identified.

surface area is $816 \mathrm{~km}^{2}$ and the maximum depth is 60 $\mathrm{m}$.

\section{Material and methods}

Monthly surveys were made from August 1985 to August 1986 at three stations (I, II and III, Fig. 1), taking samples at $0,1,2.5,5,7.5,10,15,20 \mathrm{~m}$ and $1 \mathrm{~m}$ above the sediment. Samples for the measurements of algal primary production and bacterial secondary production were taken with a Van Dorn sampler and those for chlorophyll $a$ determination by a pumping system. Water temperature was measured directly in the pumping system with a thermometer. Total chlorophyll was determined by Lorenzen's method (1967). Primary production was measured in situ in light and dark bottles, inoculated with $4 \mu \mathrm{Ci}$ of $\mathrm{NaH}^{14} \mathrm{CO}_{3}$. This were incubated for four hours over mid-day and the contents then filtered through $0.45 \mu \mathrm{m}$ membrane filters. Filters were placed in vials, allowed to dry and solubilized with $1 \mathrm{ml}$ ethyl acetate. After adding $10 \mathrm{ml}$ toluene scintillation solution, radioactivity was mea- sured with a Beckman LS-100 Liquid Scintillation Counter. Quenching was determined by the standard ratio method.

Bacterial production was also measured at noon according to Fuhrman \& Azam (1982) modified according to Riemann (1984). Duplicate $50 \mathrm{ml} \mathrm{sam}$ ples were inoculated with $2.5 \mathrm{nM}$ (methyl ${ }^{3} \mathrm{H}$ ) thymidine, 50-80 $\mathrm{Ci} \mathrm{mmol}^{-1}$ (New England Nuclear Corp., Boston, Mass., USA). The reaction was stopped by the addition of formalin to a final concentration of $2 \%$. Bacterial production was calculated according to Bell et al. (1983).

The conversion factors derived were determined according to the following protocols. In the first experiment (May, August, December, 1985 and July, 1986), five liters of surface water from Station I were incubated at room temperature. Subsamples $(50 \mathrm{ml})$ were removed at 4-hourly intervals up to a maximum of 48 hours. These sub-samples were inoculated with 2.5 $\mathrm{nM}$ (methyl- ${ }^{3} \mathrm{H}$ ) thymidine and incubated for $1 \mathrm{~h}$, then fixed and processed as described above. In the second experiment the same procedure as that described above was followed by adding $5 \mathrm{mg} \mathrm{l}^{-1}$ of glucose 

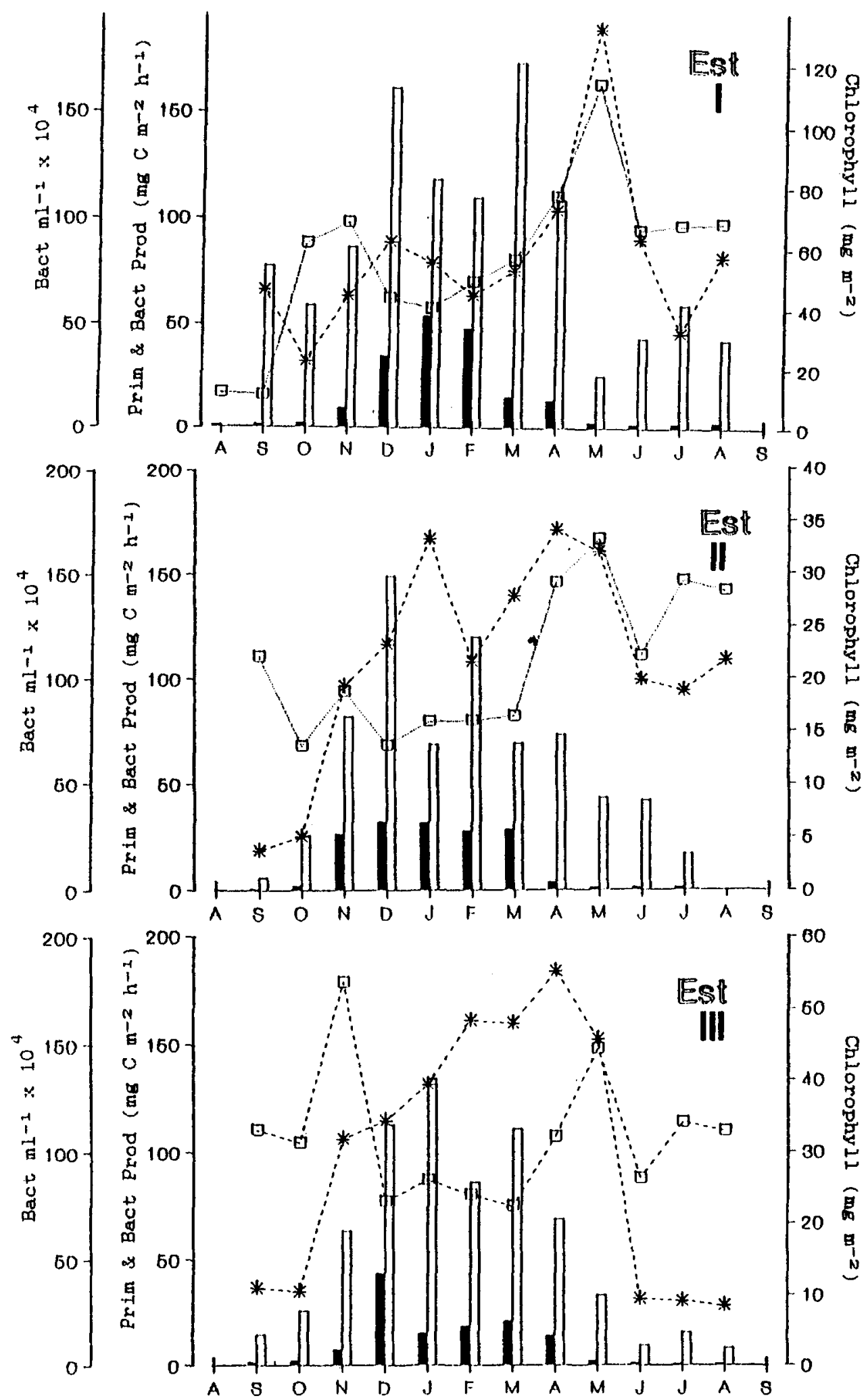

Fig. 2. Seasonal variation of primary production $\square$, secondary production $\mathbf{Q}$, chlorophyll $*_{-}$- $*$ and bacterial number $\square$. $\square$ (mean values of water column) in Ezequiel Ramos Mexía Reservoir. 


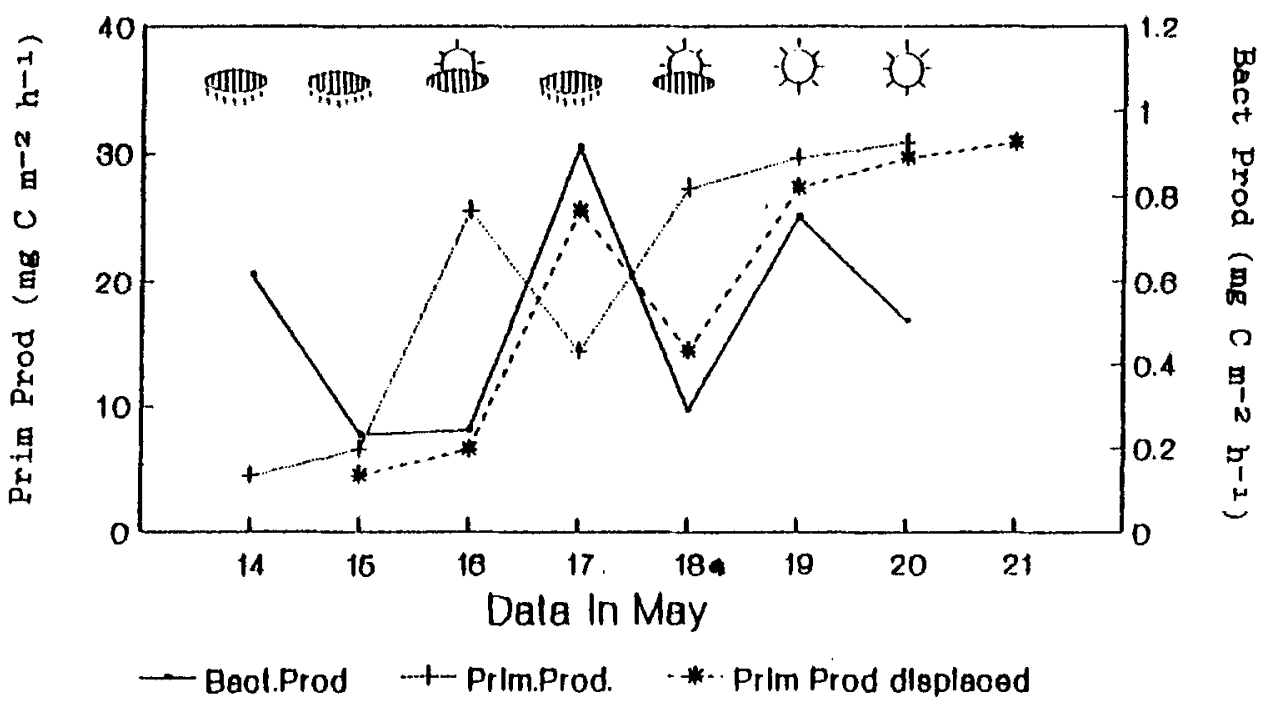

Fig. 3. Variation of primary and secondary production during a weekly study at station IV on Ezequiel Ramos Mexía Reservoir. Weather conditions are indicated (rainy, cloudy and shine).

in the water sample, to stimulate growth. Sub-samples were removed at $0,3,6,12$ and $24 \mathrm{~h}$. In the third experiment water samples were filtered through a 30 $\mu \mathrm{m}$ plankton net and inoculated with $0.3,0.6,1.2,2.5$, and $5 \mathrm{nM}$ of (methyl ${ }^{3} \mathrm{H}$ ) thymidine. Triplicate subsamples were removed at $0,4,8,12,20$ and $28 \mathrm{~h}$, fixed and processed as described above.

Samples $(5 \mathrm{ml})$ for Acridine Orange Direct Counts were placed in vials and preserved with formalin $(2 \%$ final concentration).

Conversion factors (cell $\mathrm{nmol}^{-1}$ ) were calculated as described by Kirchmann et al. (1982), modified by Bell et al. (1983). The final equation is

$$
C: \mu \frac{N(0)}{V(0)}
$$

where $\mu$ is the specific growth rate (hour $^{-1}$ ) determined from uptake rates and abundance regresssions, $N(0)$ is the initial number of bacteria incorporating thymidine and $V(0)$ is the y-intercept (initial measurement) of the uptake rate regression.

\section{Direct microscopic counts}

Bacteria were counted and cell volumes were estimated by the Acridine Orange Direct Count technique (Hobbie et al., 1977), with the following protocols from earlier publications being used. Nuclepore filters $(0.2$ $\mu \mathrm{m}$ pore size) were stained with Irgalan black accord- ing to Jones \& Simon (1975). After filtration and whilst still moist, the filters were mounted on a drop of vaseline on a microscope slide. Another drop was placed on top of the membrane before sealing with a coverslip. The slide was inspected immediately under an oil immersion objective, using Carl Zeiss immersion oil, at a magnification of $\times 1250$ with a Zeiss Standard 14 microscope. The microscope was equipped with a 100 W halogen lamp, BP 455 and BP 490 excitation filters, a FT 510 reflector and LP 520 barrier filter. Rods and cocci were grouped into several size classes and volume was calculated for each using mathematical formulae for spheres and cylinders. Cell volume was converted to carbon biomass by multiplying $1.21 \times 10^{-13}$ g C $\mu \mathrm{m}^{-3}$ (Watson et al., 1977).

\section{Measurement of short-term changes in productivity}

Algal and bacterial production were measured simultaneously at mid-day for seven days, at station IV (Fig. 1), in May 1986. Diel variations in primary and secondary production were also measured in April and May 1986. All samples were incubated in situ and the methodology was as that described above. 


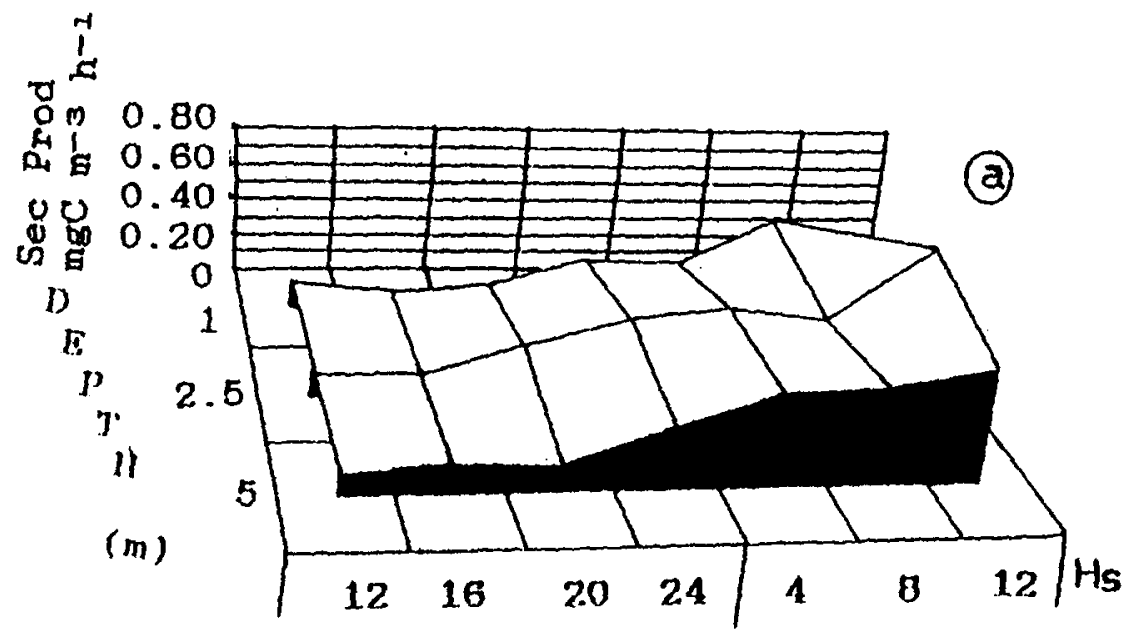

$\begin{array}{lllllllll} & \mathrm{p} & \mathrm{1} & 2 & \Lambda \mathrm{p} & \mathrm{i} & 3\end{array}$

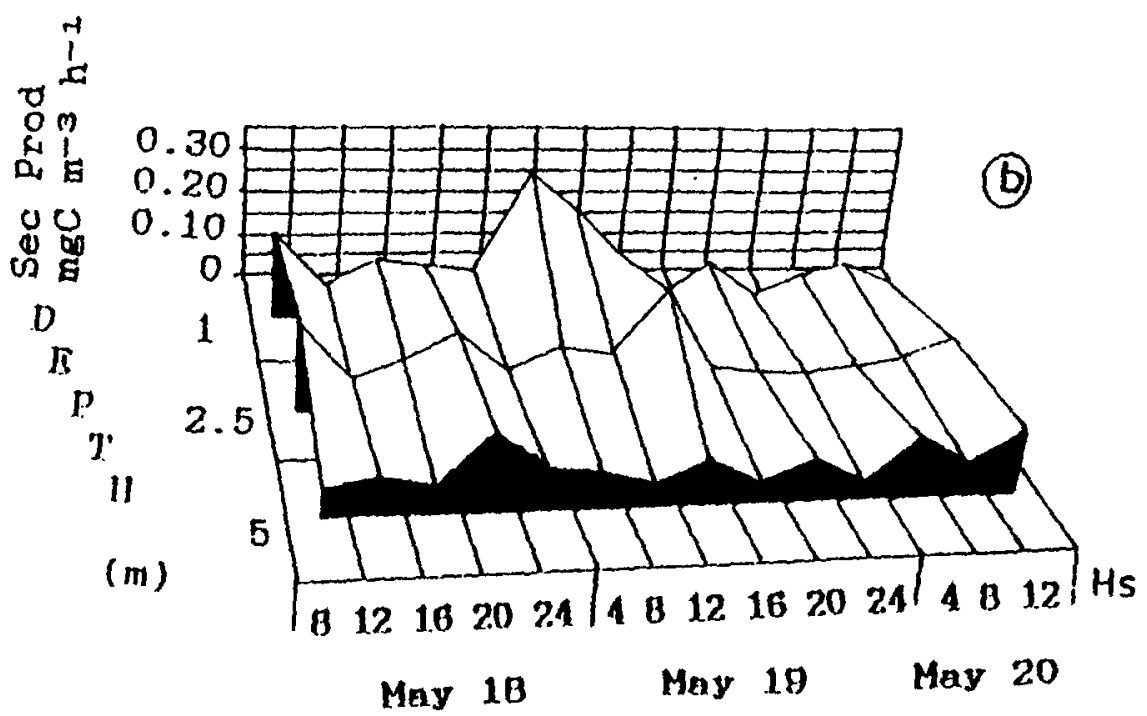

Fig. 4. Diel studies of bacterial secondary production at Ezequiel Ramos Mexía Reservoir.

\section{Results and discussion}

Bacterial secondary production was calculated, of necessity, as a range determined by the use of two conversion factors, the maximum and the minimum of those values empirically obtained, and expressed as the mean of this range. The factors were $2 \times 10^{9}-$ $1.08 \times 10^{10} \mathrm{cel} \mathrm{nmol}^{-1}$ for the cold months and $1.08 \times 10^{10}-3.3 \times 10^{10} \mathrm{cel} \mathrm{nmol}^{-1}$ for the warm months (November to April). The maximum values for bacterial production were observed during summer with values of $54 \mathrm{mg} \mathrm{C} \mathrm{m}^{-2} \mathrm{~h}^{-1}$ at station I (January), 32 mg C m ${ }^{-2} \mathrm{~h}^{-1}$ at station II (December) and $21 \mathrm{mg}$ $\mathrm{C} \mathrm{m}^{-2} \mathrm{~h}^{-1}$ at station III (March). The lowest values obtained always occurred during the winter months. A similar trend was observed with the measurements of primary production (173 $\mathrm{mg} \mathrm{C} \mathrm{m}^{-2} \mathrm{~h}^{-1}$ March, 149 $\mathrm{mg} \mathrm{C} \mathrm{m}{ }^{-2} \mathrm{~h}^{-1}$, December, and $134 \mathrm{mg} \mathrm{C} \mathrm{m}{ }^{-2} \mathrm{~h}^{-1}$, January) in the stations mentioned above.

The temperature of the water during the study period ranged between 6 and $20^{\circ} \mathrm{C}$ and had a clear influence in both processes. Bacterial secondary production as percentage of primary production ranged between $2 \%$ in June and $45 \%$ in January. Assuming a growth effi- 
ciency of $60 \%$ (Hagström, 1984), bacterial production could range from $4 \%$ to $76 \%$ of primary production. Given that bacterial production may occur over the whole $24 \mathrm{~h}$ period and that primary production is limited by the availability of light, bacterial production (as percentage of primary production) could well be calculated to increase to $182 \%$ (in summer) and $10 \%$ (in winter).

We noted, however, that at one sampling point, the number of bacteria recorded was largest during a period at which the secondary production was at its lowest. Similar patterns of response were observed at station II. At station III, there was a pronounced increase in bacterial production during the warm months, specially in December whereas the greatest number of bacteria were recorded in the cold months (Fig. 2).

In general terms there was a positive correlation between primary production (and chlorophyll $a$ concentration) and the number (total count) of bacteria and their productivity.

The temperature regime in Ramos Mexía Reservoir is relatively reproducible as judged by the depth/temperature profile. Rates of primary production apparently related to the light changes, being low on the first two days, (rainy), increasing on the third (half cloudy) and low on the fourth (rainy). Production increased from the fifth day (half cloudy) and remained stable at high values on the last two days (totally clear). Differences in mid-day secondary production were also recorded ( 0.23 to $0.91 \mathrm{mg} \mathrm{C} \mathrm{m}^{-2} \mathrm{~h}^{-1}$, Fig. 3). There was an apparent, universe relationship with primary production which was equivalent to a displacement of 24 hours (Fig. 3). During the first diel sampling programme we demonstrated that the values of primary production at noon were similar on both days ( 91 and $89 \mathrm{mg} \mathrm{C} \mathrm{m}^{-2} \mathrm{~h}^{-1}$ ). Secondary bacterial production was in general very low. The results at noon indicated that $0.5 \%$ and $2 \%$ of the primary production was converted into bacterial biomass but this value could reach $4 \%$ if the whole sampling period was taken into account.

There was no correlation in time between the maximum production of bacterioplankton and primary production, as the former rose steadily, reaching a maximum after dark (Fig. 4a). The analysis was then repeated with samples taken every four hours over three consecutive days. Values at noon were: primary production 27-31 $\mathrm{mg} \mathrm{C} \mathrm{m}^{-2} \mathrm{~h}^{-1}$ and bacterial production 0.29 $0.72 \mathrm{mg} \mathrm{C} \mathrm{m}^{-2} \mathrm{~h}^{-1}$ (1-2\% of primary production).

The pattern of secondary production was more complex in May than in April as can be clearly seen from Fig. 4. At least part of these shifts might be explained by sedimentation of the primary producers and increased activity at the sediment-water interface caused by wind induced turbulence. Novitsky (1983) suggested that interface zone is an important area for heterotrophic activity and in this instance may be attributed to the fact that the zone comprises the bed of the former Limay River. Bacterial production was calculated as a range given the uncertainty about the number of organisms which may have entered the 'starvation survival' phase (Morita, 1983) as indicated by the large numbers of cells of $<0.2 \mu \mathrm{m}$ diameter. The increase in activity may correlate with bacterial multiplication (Novitsky, 1983) possibly in response to primary producer activity. Bacterial activity may exhibit daily cycles which may in part be due to the application of different methods in different environments. Generally, these cycles exhibit peaks at sunrise, sunset and at night, markedly out of dephase with primary production (Moriarty et al., 1985; Riemann et al., 1982; Hagström, 1984; Riemann \& Søndergard, 1984; Bell, 1984). Such behaviour is not inexplicable because DNA synthesis does not show an immediate response to nutrient supply, therefore, the result of an incubation at noon is not perhaps representative of reality. On cloudy days, the rate of incorporation of (methyl- ${ }^{3} \mathrm{H}$ ) thymidine was similar or higher in the afternoon, then at sunset or at night. These results might suggest the existence of daily cycles of bacterial production and even of shorter cycles within the same day.

The complexities involved in comparing short (hourly) and longer term measurements are considerable. They may well be a requirement to separate the direct and indirect (i.e. via photosynthesis) effect of light on bacterial production. In the meantime it remains important to council caution when comparing the results obtained on differing time scales.

\section{Acknowledgements}

We greatly thank J. G. Jones for valuable comments on the manuscript and language correction, and to the referee for his critical remarks.

\section{References}

Bell, R. T., 1984. Thymidine incorporation rates and bacte- 
rioplankton dynamics during early spring in Lake Erken. Arch. Hydrobiol. Beih. Ergebn. Limnol. 19: 81-89.

Bell, R. T., G. M. Ahlgren \& I. Ahlgren, 1983. Estimating bacterioplankton production by measuring $\left({ }^{3} \mathrm{H}\right)$ thymidine incorporation in a eutrophic swedish lake. Appl. envir. Microbiol. 45: 1709-1721.

Cole, J. J., S. Findlay \& M. L. Pace, 1988. Bacterial production in fresh and saltwater ecosystems: a cross-system overview. Mar. Ecol. Prog. Ser. 43: 1-10.

Fuhrman, J. A. \& F. Azam, 1982. Thymidine incorporation as a measure of hetrotrophic bacterioplankton production in marine surface waters: evaluation and field results. Mar. Biol. 66: 109-120.

Fuhrman, J. A., R. W. Eppley, A. Hagström \& F. Azam, 1985. Diel variations in a bacterioplankton, phytoplankton, and related parameters in the southern California Bight. Mar. Ecol. Prog. Ser. 27: 9-20.

Hagström, A., 1984. Aquatic bacteria: Measurements and significance of growth. In M. J. Klug y C. A. Redd (Eds.), Current Perspectives in Microbial Ecology. American Society for Microbiology, Washington D. C.: 495501.

Hobbie, J. E., R. J. Daley \& S. Jasper, 1977. Use of Nuclepore filters for counting bacteria by epifluorescence microscopy. Appl. envir. Microbiol. 33: 1225-1228.

Jones, J. G. \& B. M. Simon, 1975. An investigation of errors in direct counts of aquatic bacteria by epifluorescence microscopy, with reference to a new method for dyeing membrane filters. J. Appl. Bact. 39: 317-329.

Larsson, U. \& A. Hagström, 1982. Fractionated phytoplankton primary production, exudate release and bacterial production in a Baltic eutrophication gradient. Mar. Biol. 67: $57-70$
Lorenzen, C. J., 1967. Determination of chlorophyll and phaeopigments: Spectrophotometric equations. Limnol. Oceanogr. 12: 343-346.

McManus, G. B. \& W. T. Peterson, 1988. Bacterioplankton production in the nearshore zone during upwelling off central Chile. Mar. Ecol. Prog. Ser. 43: 11-17.

Moriarty, D. J. W., P. I. Boon, J. A. Hansen, W. G. Hunt, I. R. Poiner, P. C. Pollard, G. W. Skyring \& D. C. White, 1985. Microbial biomass and productivity in seagrass beds. Geomicrobiol. 4: 21-51.

Morita, R. T., 1983. Starvation of heterotrophs in the marine environments. Adv. microbiol. Ecol. 6: 171-198.

Novitsky, J. A., 1983. Heterotrophic activity throughout a vertical profile of seawater in sediment in Halifax Harbor, Canada. Appl. envir. Microbiol. 45: 1753-1760.

Riemann, B., 1984. Determining growth of natural assemblages of freshwater bacteria by means of ${ }^{3} \mathrm{H}$-thymidine incorporation into DNA: Comments on methodology. Arch. Hydrobiol. Beith. Ergebn. Limnol. 19: 67-80.

Riemann, B. \& M. Søndergaard, 1984. Measurements of diel rates of bacterial secondary production in aquatic environments. Appl. envir. Microbiol. 47: 632-638.

Riemann, B., J. Fuhrman \& F. Azam, 1982. Bacterial secondary production in freshwater measured by ${ }^{3} \mathrm{H}$ thymidine incorporation method. Microbiol. Ecol. 8: 101114.

Sharp, J. H., 1977. Excretion of organic matter by marine phytoplankton: do healthy cells do it? Limnol. Oceanogr. 27: 381-399.

Watson, S. W., T. J. Novitsky, H. L. Quinby \& F. W. Valois, 1977. Determination of bacterial number and biomass in the marine environment. Appl. envir. Microbiol. 33: 940 947. 